\title{
An Evolutionary Psychological Perspective on a the Development of Individual Differences
}

\author{
Jan Guus Waldorp* and Harry van de Wiel \\ University of Groningen, University Medical Center, Europe
}

Submission: July 24, 2017; Published: July 28, 2017

*Corresponding author: Jan Guus Waldorp, Wenckebach Institute, University of Groningen, University Medical Center, Groningen, The Netherlands, Europe, Email: waldorp@mindlogyx.com

\section{Introduction}

Due to genetic inheritance and their experience with the environment, people are markedly different from one another, not just physically but also mentally. Therefore the issue of this succinct introduction is: why do individuals vary and how and when do individual differences develop? In search for an answer to these questions, we recently developed a theory for an evolutionary psychological explanation for the development of individual differences. One of the main reasons for developing a novel theoretical approach is that evolutionary psychology (EP) currently lacks its own framework for identifying and explaining individual differences. Based on our findings we constructed hierarchal Evolutionary Taxonomy of Motivation ( $E$ to $M$ ) that we then correlated with the traits of the five factor model (FFM). Thus $\mathrm{E}$ to $\mathrm{M}$ is more than just a useful tool for categorizing individual differences, it also allows for understanding, explaining and predicting individual behavior.

\section{Why Individuals Vary}

People are different, but why? According to evolutionary theory individual differences are essential for sexual selection, the process that creates and maintains functional adaptations in natural selection Hawley and Buss [1]. EP builds on Darwin's theory on secondary sexual ornaments which implied there are separate indicators to advertise an individual's evolved fitness to other individuals. In humans, with a brain that is the largest of all animals in relation to body size, this organ is a sexually selected mental indicator of fitness Miller [2].

\section{Fundamental Adaptations}

To understand why people vary and what is at stake for the individual, we have to look at what is needed to be successful in evolutionary terms. Fitness, the measure of an individual's direct reproductive success by passing on his genes, is too narrow a concept as seen through the gene's eye view Dawkins [3].
Inclusive fitness Hamilton [4] in evolution means helping family members that carry the same genes to reproduce. Nevertheless, all individuals have to deal with three different social challenges in life that is all linked to fundamental adaptations: forming and maintaining long-term relationships, being able to cooperate with members of one's in group and competing successfully with one's rivals.

\section{When and how do Individual Differences Develop?}

Research has demonstrated that individual differences are relatively stable over the years which make it even more compelling to understand how and when individual differences develop. Individual differences are the result of the interaction between genes and the environment. Individual stability is probably largely due to genetic inheritance Plomin [5]. So far, however, what percentage of the individuals' psychological makeup is due to its genes or the environment remains, except in some instances, unclear.

What is clear, however, is that due to its large brain that allows for developmental plasticity "novel features of hominid evolution such as high intelligence, language, sophisticated tool use, and an immense expansion in cultural traditions and learning" humans occupy what is called the 'cognitive niche' Tooby [6].

Within this universal human cognitive niche however, individual differentiation is needed. It appears that people differ in their quality of solving particular psychological social problems. This is logical because there is no optimum for all situations in all contexts and some kind of 'specialization' is basic to all people. Competition for instance, according to Hawley's strategies of resource control Hawley [1] may be expressed as coercive strategies of resource control through threatening and taking or prosocial strategies of resource control that relies 
on friendship, cooperation and reciprocity. By comparison phenotypic polymorphism in wild populations is rather large: very early in life an animal picks up a cue from the environment like some kind of 'weather forecast' such as grasshoppers rise against a black background and become black instead of green Nettle [7]. Similarly a toddler picks up cues from the social environment (i.e. parental investment, allocation of resources) and through deontic reasoning Cummins [8,9] based on its gene $\mathrm{X}$ environment interaction non consciously 'chooses' what we have called its social strategy, a strategic differentiation Hawley [1] that will stay with the individual for the rest of its life.

\section{Three Fundamental Adaptations}

The human mind seems to have evolutionarily 'anticipated' such a developmental specialization. It contains three different mental systems, one for affective relationships and one for cooperation and one for competition, to deal with each of the social challenges separately Harris. The systems develop through different processes in the brain, follow different neural paths and are stored in different parts of our memory system Lewis [10]. One of these systems will eventually lead to a specific motivational profile that guides the social strategy of the individual. Early development is fundamental because neural plasticity is time-sensitive, not infinite and does not provide an optimal phenotype for all contexts Nettle [7].

\section{Conclusion}

Based on our evolutionary psychological literature we have construed that the information is sufficiently reliable to come to our conclusions. Obviously more research and empirical evidence is needed but for the time being our conclusions seem to pan out [11]. In the near future we hope that further empirical research may draw definitive conclusions but we believe to have developed a promising route that eventually will increase our understanding of individual differences.

\section{Reference}

1. Hawley PH, Buss DM (2011) Introduction in the evolution of personality and individual differences, David M Buss and Patricia $\mathrm{H}$ Hawley (Eds.) Oxford University Press, UK.

2. Miller GF (2000) Mental traits as fitness indicators: Expanding evolutionary psychology's adaptationism. In: D LeCroy, P Moller (Eds.), Evolutionary perspectives on human reproductive behavior. New York Academy of Sciences 907: 62-74.

3. Dawkins R (1976/1989) The selfish gene. Oxford University Press, UK.

4. Hamilton WD (1964) The genetical evolution of social behavior (1) Journal of theoretical biology, 7: 1-16.

5. Plomin R, DeFries JC, Knopik VS, Neiderhiser JM (2016) Top 10 Replicated Findings From Behavioral Genetics. Perspectives on Psychological Science 11(1): 3-23.

6. Tooby J, DeVore I (1987) The Reconstruction of Hominid Behavioral Evolution through Strategic Modeling, In: Warren G Kinzey (edn.), The evolution of human behavior: primate models. SUNY Press, New York, USA.

7. Nettle D (2011) The evolution of personality and individual differences, in The evolution of personality and individual differences. In: David M Buss and Patricia H Hawley (Eds.), Oxford University Press, UK.

8. Cummins DD (1996) Evidence for the innateness of deontic reasoning. Mind and lnaguage 11(2): 160-190.

9. Cummins DD (1996) Evidence of deontic reasoning in 3 and 4 year old children. Memory and cognition 24 (6): 823-829.

10. Lewis MD (2005) Self-organizing individual differences in brain development. Developmental review 25: 252-277.

11. Harris Rich J (2011) Explaining individual differences in personality: why we need a modular theory, in the evolution of personality and individual differences. In. David M Buss and Patricia H Hawley (Eds.), Oxford University Press, UK.

This work is licensed under Creative Commons Attribution 4.0 License

DOI: 10.19080/PBSIJ.2017.05.555662

\section{Your next submission with Juniper Publishers} will reach you the below assets

- Quality Editorial service

- Swift Peer Review

- Reprints availability

- E-prints Service

- Manuscript Podcast for convenient understanding

- Global attainment for your research

- Manuscript accessibility in different formats

( Pdf, E-pub, Full Text, Audio)

- Unceasing customer service

Track the below URL for one-step submission https://juniperpublishers.com/online-submission.php 